I wish to protest to The Forestry Chronicle for printing one of the gay limericks in Participation 4. If DMN is going to employ a four letter word then surely he should have the courage to write the word in full. Dashing or asterisking the word to death only achieves the purpose of reducing the Chronicle to the level of such magazines as Penthouse, Cavalier, Knight, Lui, etc., where sex and four letter words are to be sniggered at.

Let's call a spade a spade, not a sp-d*.

Sherry Hambly

Oshawa, Ont.

\title{
ERROR IN REVIEW
}

\section{Forum}

\section{Resource planning 1}

Planning of the forestry resource must first have a defined communication policy aimed at making a public awareness of the processed and coordinated interaction between controlled-clearcut management and the locked-up wilderness concept.

Forestry oriented research must be a decision programmed framework organized to obtain the maximized capability of a public generated budget.

The cost-benefit concept cannot be used in environmental decision making because policy decisions, generated by forestry resource management personnel, are defined strategy solutions to ecology awareness problems.

A coordinated thrust generated by determined and organized pressure groups on public resource management agencies will lead to modified decision making. This will provide for an aesthetic, and environmental quality resource that leaves the primary wood using industry in the problem-generated wilderness where the ecologyoriented public was determined to be in the first place. (See also p. 172 for further discussion of this subject.)

\section{J. B. Atherton}

\section{Resource planning 2}

Item 1. A news release from the Ontario Professional Foresters Association headed Forest Regeneration in Ontario Inadequate. "In spite of warnings by prominent foresters during the last 60 years that forest regeneration must be an integral part of harvesting practices, support by government for regeneration has been woefully inadequate. Industry must share with government the responsibility for this failure."

Item 2. A coloured propaganda fold out from the Ontario Ministry of Natural Resources entitled Out of the Woods .... Superimposed against an oblique view of a jack pine forest, a triple photo shows a heavily laden, red-coloured pulpwood truck roaring ever closer on a dusty road. The text tells how much comes out of the woods and what great benefits these products yield for the people of Ontario economic growth, prosperity, prestige. Photos show mills, paper products, lumber, plywood, trimming, felling, skidding, hauling, pruning and so on. A gravel road, well-cleared to the sides, cuts a wide swath through a forest. And is anything put back into the woods? It doesn't say. Do those tubed seedlings shown in a discreet photo on the cover provide the clue?

D. C. F. Fayle
I would like to point out an error that occurred in the printing of the review of Clepper's book on Professional Forestry in the United States (Forest. Chron. 48:144). The last sentence should read: "Finally, it will help him to make his own judgment of the relative merits of predominant private ownership of woodlands characteristic of the United States and continued public ownership to which he is accustomed at home." (Bold face indicates the words that were left out.) J. D. B. Harrison

Ottawa, Ont.

\section{FORESTRY MATERIAL SOUGHT}

I teach forest science at a College of Agriculture in Brazil to about one hundred students. However there is a scarcity of printed material on forest science here and it is difficult to obtain it in Brazil.

We would very much appreciate it if people would send material to our library so that we can build up material for the students to use. The address is: Setor de Silvicultura, Escola Superior de Agricultura de Lavras, Lavras, Minas Gerais, Brasil. Nelson Ventorim Brazil

\section{NAMES, NAMES, NAMES}

Re: "What's in a name?" in the June issue.

Touché.

Pat Duffy

Cross-Mission Co-ordination Division Program Planning Branch (Formerly Integration Branch)

Policy, Planning and Research Service Department of the Environment

\section{MANAGE BY WATERSHEDS}

In the summary prepared by Anatole Coté of Quebec's White Paper on Forest Policy - Volume I (Forest. Chron. 48:84-87) I noticed the statement: "Management units should correspond to watersheds and not with county lines, township lines, etc." I am glad to hear that at least one provincial government is intimating management of forest lands by adherence to 'natural' boundaries rather than to artificial boundaries. Although much research is being conducted on a 
watershed basis, especially in the Rocky Mountain foothills of Alberta, and some planning is being carried out in accordance with river drainage areas (particularly the Conservation Authorities of Ontario) most of the managed forest land in Canada is dissected into units based primarily on ease of administration and/or of extraction. Nature is not artificial. If any manipulation of natural landscapes is considered necessary, this manipulation should be managed and monitored within units that are tied to nature rather than to administration.

$A$ watershed unit seems to be a logical natural unit to choose. Not only is it easy to delineate one from another or a smaller one within a larger one (a hierarchical system of management units could be set up from macro-regional watersheds down to individual creek watersheds if desired), but watersheds also tend to be very suitable units for research into and evaluation of management practices.

Cheers for the Quebec Government. Let us hope this is the beginning of a trend across Canada.

H. E. Hirvonen

Victoria, B.C.

\section{ETYMOLOGICALLY SPEAKING}

Some of your readers will do doubt visit, or may have already visited, beautiful B.C. in the summer of '72. Of the many attractions here, they may note, or may have noted, several trucks and campers boldly emblazoned "U. B. C., Forest Recreology". I would like to re-assure your readers that I, for one, suspect (and hope) that this does not really mean what they or I at first thought it meant, either in this context or in its increasingly frequent appearances in print.

Forgive the pedantry, please, but isn't logos from the greek, meaning "the study of" or "the knowledge of"? and re- might easily be from the latin, meaning "again". Likewise credere from the latin "to believe". Since the latter two words are both latin, one may string them together, producing the word recredere, which according to the dictionaries l've consulted is the root for "recreant", meaning a person who "reconsiders his views or beliefs under duress", or, less euphemistically, is a craven coward. Good Grief!! Is recreology (let us ignore the purist's claim that one should not compound words of different languages) the study of deserters (a viable discipline perhaps, but of rather marginal relevance to forestry)? Not at all, let's be charitable. The sign-painter could not quite read his instructions. It's Forest Recreation, latin root recreatus "to renew"I Or is it Forest Recreatology? No, that won't do, it's a hybrid word. Eureka! The entirely greek version we need is thiaskethasisiology (what mellifluousness!) from the greek thiaskethasis, "recreation". But can we afford the paint and ink?

John Worrall

Vancouver, B.C.

\section{"Whispers through the trees"}

Have you noticed how many people are prejudiced for or against different kinds of trees? Likes and dislikes can be held quite vehemently, and since the subjects of abuse are mute and cannot cry out for justice, such arboreal animosities as are held do not receive public attention.

Personally, I have always thought of deciduous trees as rather fickle creatures. Slim and graceful in their youth, they persist in an annual adornment of new clothing each spring and as the summer progresses grow faded and spotty. As if to compensate they often attempt a final fall display of colour and then in resignation shed their coverings and expose their limbs for all to view. Sleek and supple in their youth, as they age the summer canopy becomes fuller and in autumn as each foliar chemise is dropped the fullness and curves of their limbs are attractive to all who pass by. Just as there is a certain sameness about young girls even though their shapes and sizes may vary, there is a like uniformity about young hardwoods. However, as they develop and mature the individual differences become pronounced. Look at Miss Quercus in her late twenties or early thirties, sturdy limbed with a no-nonsense look even when naked on a sunny day in April. Even the lobing of her leaves has a Victorian look about it. In contrast the sleek, smooth-skinned Beech woman dances through the winter with her sharp-pointed finger tips; and as she reaches her full maturity she will likely take some bear to her bosom and then brazenly display the traces of his caress for years to come.
As these tree creatures age, the wrinkles and lines are the outward signs of their long lives, but less obvious are the seams and cracks and internal deterioration which have taken place. Even the 'kept' woman in a park or garden may bear the scar of black paint where a rotten limb has been excised to suit her master. With old age the deciduous ladies take on the appearance of gnarled old harridans. In their final few years they scarcely can clothe themselves even in summer and attract but a few crows and woodpeckers.

A complete contrast are the conifers - the puritans of the woods. As if to make up for their foetal nakedness they spend the remainder of their lives from birth continually clothed, Well, there are a few exceptions like the racy, precocious larches which do not cover up completely even in summer! Not only are the conifers marked by modesty, but also by an industriousness that makes them beloved of foresters. As long as they receive adequate moisture and warmth, they plod along, not like the harum-scarum deciduous trees which stop work in the fall and spend a good part of their lives in wanton display. The conifers also exhibit another characteristic - they are amenable to discipline and prefer a well-ordered life and arrangement. It now is clear why the beginnings of forestry are to be found in the German management of conifers. Ja!

Nemorensis

There is more bounce to the ounce In $a$ ball that falls

Than a rock that drops Sayings of $Y_{0}-Y_{0}$ 


\section{Buzzword generator aids communication?}

Participation 6 generated four entries this time still nothing from the Maritimes. A. M. D. Todd (Houston, B.C.) writes: "I am a recent graduate and have found employment deep, deep, deep in the interior of B.C. with the Forest Service. To keep myself entertained I have relied on The Forestry Chronicle ..." Brian J. Myers participated from Canberra, Australia and used the least amount of helper words. Although Ken R. Elliott (Ottawa) used the greatest number of helper words, he deserves credit for his masterful composition - the buzzwords were placed in alphabetical order. J. B. Atherton (Espanola, Ont.) has a very nice twist in the last paragraph of his participation although he failed to use 7 of the buzzwords and repeated others.

In Resource Planning, JBA states that we must have a communication policy and he outlines a framework for forest research. AMDT provides some background to the communication problem in A Planned Mouthful. KRE supplies a Communication Concept and BJM outlines some thoughts on forestry research in Forestry Reforms.

\section{Resource Planning}

Planning of the forestry resource must first have a defined communication policy aimed at making a public awareness of the processed and coordinated interaction between controlled clearcut management and the locked-up wilderness concept.

Forestry oriented research must be a decision programmed framework organized to obtain the maximized capability of a public generated budget.

The cost-benefit concept cannot be used in environmental decision making because policy decisions, generated by forestry resource management personnel are defined strategy solutions to ecology awareness problems.

A coordinated thrust generated by determined and organized pressure groups on public resource management agencies will lead to modified decision making. This will provide for an aesthetic, and environmental quality resource that leaves the primary wood using industry in the problem generated wilderness where the ecology oriented public was determined to be in the first place.

\section{A Planned Mouthful}

Public awareness and pressure, oriented with thrust toward environmental forestry, resource management, pollution, ecology, wilderness research and the aesthetic modified clearcut concept indicates communication. The mission, defined by policy, is identifying the generated problem, making an organized and coordinated decision, and planning a solution processed in a controlled and programmed framework including a projected budget of maximized benefit-cost strategy. A containerized tactic or locked up factor, it is a determined performance of departmental capability and interaction.

\section{The Communication Concept}

An aesthetic awareness will benefit the budget capability and make a clearcut case for the communication concept if such is containerized, controlled and coordinated. The cost of such a decision can be defined and determined by the ecology but the environmental factor within the forestry framework must be a generated interaction. This concept is locked up by making management a maximized mission, modified by organized effort oriented to peak performance, but the planning policy must be free of pollution and pressure or a problem will develop unless processed and programmed to be projected to the public. The quality of the research resource will determine a solution for this strategy tactic or thrust it into the wilderness.

\section{Forestry Reforms!}

A coordinated forestry research concept oriented toward making a policy decision on the problem of aesthetic environmental management was determined by programmed, maximized, benefit cost strategy; organized public awereness capability; modified wilderness resource ecology (no pollution); and thrust generated communication interaction (defined as "processed planning under pressure"). Moreover, the quality controlled performance factor within the locked up, containerized framework of the projected budget tactic indicated the mission had a clearcut solution.

Although not an entry to Participation 6 we feel that whoever wrote the speech for Dr. E. R. Tinney (Environment Canada) to the Annual Meeting of the Conservation Council of Ontario could have "won". Part of that speech reads "We are developing research strategies, coordinating research activities, and ensuring that programs in the missionoriented Services are consistent with the Department's overall policy direction".

Percy Sims and Gus Steneker (Edmonton) spied this piece in a book review in American Scientist (60/1:80): "Its distinguished style, breadth of humanistic reference and catholicity of implicit psychological sophistication are paradoxically dissonant with the bare-bones simplism of Skinner's explicit methodological strategy and his psychological principles." 


\section{* 40 \& 20 Years}

\section{Forestry schools}

September 1932. The Quebec Forestry School was established in 1910. It is affiliated with the Laval University and subsidized by the Government. The course's duration is three years. Bachelors of Arts and Sciences are admitted without an examination, others have to pass a University examination on letters and sciences. The program includes higher mathematics, special chemistry, dendrology, soils, reforestation, sylviculture, dendrometry, hydraulics, construction, surveying, forest industries, technology, forest protection, forest management, forest economy, history of sylviculture, etc. The theory is supplemented by practical work carried in a forest close to Quebec. Every year, free tuition is given to five students after a special elimination contest.

September 1952. The Faculty of Forestry (The University of New Brunswick) established in 1908 offers a Degree of Bachelor of Science in Forestry in five years after Junior Matriculation or four years after Senior Matriculation.

The Graduate Degree of Master of Science in Forestry is conferred in Forest Entomology, Logging, Forest Management, and Silviculture.

The Faculty is well equipped with lecture rooms and modern laboratories including a modern dry kiln.

Field instruction and demonstration are carried out on the 7,000 acres of forest controlled or owned by the University.

\section{Participation 8 is a travel brochure}

This time we invite you to prepare a blurb for a travel brochure or what-have-you on the attractions of a clearcut. We place no limitations in what region of the country you wish to have your clearcut, nor on the number of words. Send your entries to The Editor, the Forestry Chronicle, 17 Elizabeth St. N., Richmond Hill, Ontario. Deadline: September 30 . Offerings will appear in the December issue.

\section{"Pulp industry big polluter, Davis says"}

\author{
Little Jack Davis \\ Knows who the knave is \\ Polluting his water and sky. \\ He'll stick in his thumb \\ Until they succumb \\ And say "What a good boy am I".
}

\section{Who said this?}

"We trained hard, but it seemed that every time we were beginning to form up into teams, we would be reorganized. I was to learn that later in life we tend to meet any new situation by reorganizing, and a wonderful method it can be for creating the illusion of progress while producing confusion, inefficiency, and demoralization."

Is it from the writings of an ex-CFS employee? Or the thoughts of some recently reorganized provincial government employee? Wrong. It was a Roman author by the name of Petronius, who was a favorite of Nero and at whose court he was arbiter elegantiarum. Even his death in 66 A.D. may be symbolic for employees of rereorganized organizations. Evidently he was accused of treason and forestalled what he thought inevitable death by an eccentric suicide. He cut his veins but prolonged life for some time by the application of bandages. 